International Journal of Advanced Academic Research | ISSN: 2488-9849

Vol. 7, Issue 6 (June, 2021) | www.ijaar.org

Journal DOI: www.doi.org/10.46654/ij.24889849

Article DOI: www.doi.org/10.46654/ij.24889849.s76161

\title{
ACCOUNTING INFORMATION QUALITY AND FIRM PERFORMANCE OF QUOTED OIL AND GAS COMPANIES IN NIGERIA
}

\author{
MACGREGOR, T.C. \\ Department of Accounting \\ Faculty of Management Sciences \\ University of Port Harcourt, Port Harcourt. \\ IBANICHUKA, E.A.L. \\ Department of Accounting \\ Faculty of Management Sciences \\ University of Port Harcourt, Port Harcourt.
}

\begin{abstract}
The aim of this study is to empirically analyze the relationship between accounting information quality and firm performance of oil and gas companies in Nigeria. Time series data on different types of accounting information quality and earnings per share from 20092018 were collected from central bank of Nigeria statistical bulletin, annual central bank of Nigeria reports, National Bureau of statistic and Federal Inland Revenue Service. Ordinary Least Square regression analysis, Autoregressive Distribution Lag, Co-integration, Augmented Dickey-Fuller Unit root test, Serial Correlation and Heteroskedasticity test and Error Correction model with the aid of E-view version 10. The empirical results indicate that accounting information quality significantly relate to firm performance; explaining abut $83.1 \%$ of total variation in earnings per share, audit lag and disclosure quality were each found to significantly relate to earnings per share. We therefore conclude that accounting information quality ahs the potency to make significant contribution to earnings per share and recommends that increased scrutiny by regulators (FRCN, CBN, SEC etc) over accounting flexibilities would help to curtail accounting discretions both deliberate and systematic so that accounting information in financial statements will faithfully represent the phenomena they purport to represent and future corporate scandals on oil and gas crises can be avoided.
\end{abstract}

Keywords: Accounting Information Quality, Firm Performance, Audit Lag, Disclosure Quality and Oil and Gas Companies. 
Journal DOI: www.doi.org/10.46654/ij.24889849

Article DOI: www.doi.org/10.46654/ij.24889849.s76161

\section{Introduction}

Over several numbers of decades the performance of accounting ahs increased right from the single entry system to double entry system. The aim of the accounting is to timely provide financial data like purchase (Al-Dalabih, 2018; Denso., Hlt \& Innoff, 2019), revenue (Budairi, 2017; Ahamad, Siddiqui., Aboalsamh, 2020), expenses and income of the organization (Palazuelos; Grespo \& Delcorte, 2017; Koshif, 2018; Rehab, 2018) but in today's modern world accounts maintenance is helpful in many ways (Odar., Krauivo \& Jerman, 2017; Kashif, 2018; Saeidi, 2016). Previously accounts are maintain to know profit or loss of the organization but now a day it is also useful for increasing profitability of the organization by way of accounting information system (Mitchell., Biglan., Oniken \& Fialler, 2017; Alnojjar, 2017). Businesses include transactions which produce information for better analysis of business performance and accounting information quality is a delivery quality for accounting.

Accounting information refers to processed data generated through an accounting system where objective is to provide facts that are useful about the reporting entity to existing and potential investors, shareholders, lenders and other payables in decision making (Ironkwe \& Nwaiwu, 2018; Akambi \& Adewoye, 2018). It is among the main sources used as a means for decision making, analysis and control. Therefore, it is imperative that accounting information is of a quality to be useful to the various users, since bad accounting information quality leads to higher agency costs, asymmetry of information and provides inadequate protection to stakeholders (Teru., Idoka \& Weleyati, 2017; Akanbi., Adeweye, 2018; Borhan $\&$ Nafees, 2018). Accounting information quality contained in financial statements of firms is expected to be useful for decision making by shareholders, management, payables and lenders, investors and other stakeholders. In order to provide this, financial statements should meet some basic characteristics. It must be relevant and faithfully represent what it purports to represent. The usefulness of financial information is enhanced of it is comparable, verifiable, timely and understandable (conceptual frame, 2010.

The primary objective of accounting information is to provide high quality financial reporting information concerning economic entities, primarily financial in nature, useful for economic decisions making (financial accounting standard board) FASB, 1999, (international accounting standard board) IASB, 2008. Providing high quality financial reporting information is important because it will positively influence capital providers and other stakeholders in making investment, credit and similar resource allocation decisions enhancing overall market efficiency (IASB, 2006, IASB, 2008). Consequently, many researchers measure the quality of financial reports, indirectly by focusing on attributes that are believed to influence quality of financial reports, such as earnings management, financial restatements, and timeliness (Barth., Landsman \& Long, 2008; Schipper \& Vincent, 2013; Cohen., Krishmamorty \& Wright, 2019). The high quality of accounting information quality plays a key role in reducing information asymmetry between key stakeholders (pay others) and agents (managers) (Kim.,Miller., Wan \& Wang, 2016; Lathan., Satria \& Ilmainir, 2016). It also reduces the asymmetry of information between managers and external suppliers of capital and improves investment efficiency (Biddle \& Hilary, 2006; Forah., Ferrukh \& Faizan, 2016; Kashif, 2018; Nwaiwu, 2010). The quality of accounting information is difficult to observe and to measure through (Isidro \& Raonic, 2012; Obacidat 2017; Budairi, 2017). Moreover, there is no predominant and generally accepted agreement or approach to measure it (Yoon 2007; Mitchell; Bigkan; Onoken \& Fialler 2017; Alaajjar, 2017; Akanbi \& 
Journal DOI: www.doi.org/10.46654/ij.24889849

Adeneye, 2018). Nevertheless, the quality of accounting information can be evaluated based on attributes such as persistence, conservatism, accounting earnings management, quality of accruals measurement, transparency, disclosure level, relation of accounting figures with stock price performance or the market value reported by the companies (Dechow., Ge \& Schrand, 2010). The existence of a series of social, economic political and behavioral factors also exerts influences that contribute to the factor that the different economic agents do not possess the same information, qualitative and/or quantitatively. These factors, such as the system of governor, auditing, accounting regulation and system of standards, enforcement, taxation, legal relations of contracts, resource suppliers among others, directly affect the quality of accounting information present in the statements companies publish (Panlo., Cavalcante \& Melo, 2012; Fathi, 2013; Mike \& Kamardin, 2015).

Ohlson (2005) builds a model that reflects the relationship between accounting information and firm value. Many scholars have demonstrated the usefulness of such information by showing how investors use it to make decisions (Beaver, 1968; Ball \& Brown, 1968). Investors are concerned with the quality of accounting information because it helps them to better understand the company's operating situation and other fundamentals. High-quality accounting information affords external stakeholders a comprehensive understanding of firm fundamentals and allows them to take action to supervise management behaviour. Once management's activities are not aimed at maximizing the interests of stakeholders, major shareholders can seek to alter it by voting for changes on the board of directors and taking part in shareholder meetings. Goitom (2003), the better the quality of accounting information, the greater the possibility for a business success and this is possibly because accounting can be viewed as information measurement and communication system to serve macro and micro-economic activities. Sometimes decision makers may be fed with irrelevant and useless information than they can use, they may overlook information on serious problems (Stoner). Investment decisions made in a vacuum are gambles; useful decisions are made depending on useful information (Sierwanga 2005). Financial reporting that does not reflect economic reality will result in improper decision making.

In view of the above, it has been advocated that companies with higher quality accounting information are more likely to invest more capital in their core business and improve financial performance. Extensive empirical literature, long but large exists internationally and nationally on the effect of accounting information quality on financial performance, but the empirical results are rather mixed and inclusive (see, for example, Eb., Pretorious; Zuva, 2013; Dandago \& Rafai, 2014; Yaser., Alina \& Nor, 2014; Samer, 2016; Obaidat, 2017; Palezuelos; Crespo \& Dekarte, 2018). Unfortunately the empirical assessment of the relationship between accounting information quality and financial performance in actually investigated in Nigeria have also produced conflicting results (see Dekeng \& Prabowo, 2015; Hla \& Tern, 2015; Patel, 2015; Taiwo, 2016; Esmeray, 2016; Budiri, 2017; Al-Dalabih, 2018; Al-Dababih, 2018; Rehab 2018; Kashif, 2018; Ironkwe \& Nwaiwu, 2018; Akanbi \& Adevoye, 2018; Denos., Holt \& Imhoff, 2019). It is, therefore, possible that accounting information quality per se may not adequately address the recurring problem of dismal financial performance of oil and gas companies in Nigeria. The main objective of this empirical paper, therefore is to explore whether changes or variations in accounting information quality have significant influence on the financial performance of Nigerian oil and gas companies. This empirical study is sub-divided into five main sections including this introduction as section one. Section two presents the theoretical foundation, conceptual 
Journal DOI: www.doi.org/10.46654/ij.24889849

Article DOI: www.doi.org/10.46654/ij.24889849.s76161

framework and empirical review on accounting information quality and financial performance; it also states the hypotheses to be tested. Section three presents the methodology, while section four reports the empirical results and discussion. Concluding remark, recommendations, limitation and suggestion for further study is in section five.

\section{Literature Review and Hypotheses Development Theoretical Foundation}

Theoretically, a growing body of evidence exists in the fiancé literature pointing to the relationship between accounting information quality and quoted financial performance. This literature is really rooted in the agency framework (Jensen \& Meckling, 1976). The framework presumes fundamental tension between shareholders and corporate managers. The tension was first identified over two centuries ago by Smith (1976) with the suggestion that effective mechanisms be put in pace to ensure that corporate managers enhanced the value of the owners of firms (Dockey., Tsegba \& Herbert, 2012; Tsegba., Ene \& Herbert, 2014). Much later, however, Berle and Means (1932) proposed that managers of firms with dispersed ownership were likely to pursue suboptimal (opportunistic) goals different from the interests of the shareholders. Although, the explored the concept of agency and the applications towards the development of large corporations. They found out how the interest of the directors and mangers differs from the owners of the firm, thereby using the concepts of agency principal to explain the genesis of those conflicts. Jensen and Meckling (1970), further on the work of Berle and Means (1932), developed agency theory as a formal concept. They also formed a school of thought arguing that corporations are structured to minimize the costs of getting agents (agency costs), to follow the direction and interests of the principals. The theory essentially acknowledges that different parties involved in a given situation with same given goal will have different motivations, and these differences can manifest in diverse ways. This means that there will always be partial goal conflict among parties, because efficiency is inseparable from effectiveness, and thus information will always be somewhat asymmetric between principal and agent.

Agency theory is therefore concerned with contractual relationship between two or more persons called the gent(s) to perform some services on behalf of the principal. Both the agents and the principal are presumed to have entered into mutual agreement or contract motivated solely by self-interest. The principal delegates decision making responsibility to the agents (Alriajjar, 2017). It is a concept that explains why behaviour or decisions vary when exhibited by members of a group. Specifically, it describes the relationship between one party called the principal who delegate work to another called the agent. It explains their differences in behaviour or decisions by noting the two parties often have different goals and are independent of their respective goals and they have different attitudes toward risk. Invariably, the agents' decision and choices are assumed to have effect on both parties. These relationships, according to Tailwo (2016), are perceived in economic and business life and also generate more problems of contracting between entities in the economy. This means that there is a contractual relationship between shareholders and directors and audit committee and shareholders or between audit committee and external auditors.

Considering earnings management practice, agency theory explains clearly the existence of the incentive for management to use earnings management. Therefore, Salah (2010) ( Roel, 2017) suggests that, management could use earnings to mislead shareholders by showing a different image of the company's earnings. Additionally, Rehad (2015) pointed out that 
Journal DOI: www.doi.org/10.46654/ij.24889849

earnings management may arise as a result of information asymmetry or problem of agency conflicts that occur when equity ownership is separated from day to day operation of the corporation and managers have a comparative information advantage over shareholders and that this market imperfections create an environment for managers to engage in accounting discretion in order to promote their selfish interest at the expense of shareholders (e.g. discretional reporting lags aimed at achieving selfish interests). At the same time, they also create an opportunity for managers to sue that accounting discretion to communicate their companies" performance related information in appropriate manner with investors (Dents., Holt \& Imhof, 2019). However, because of the opportunistic behaviour of agents, it has been very paramount for organizations to provide a body that will serve as a watchdog in aligning the interest of agents and principal. One of such mechanisms is through the establishment of audit committee. In this regard, corporate governance framework of which audit committee is an integral part serves as an effective tool in achieving the expectations and the need of shareholders, thereby providing better monitoring of management which serves as an impetus of transparent and reliable reporting.

\section{Conceptual Framework}

The conceptual framework for this study is developed from the a priori to explain the relationship between the proxy of sub explanatory variable accounting information quality (relevance) and firm performance (Earnings Per Share) of oil and gas companies.

\section{Firm Performance}

The subject of corporate performance has received significant attention from scholars in the various areas of business and strategic management (Manchdoh, 2019). It has also been the primary concern of business practitioners (managers and entrepreneurs in all types of organizations because corporate performance is essential as exemplified in high performance organizations which are success stories because of their perceived effectiveness and efficiency in managing their operations and their positive contributions to the well-being of their stakeholders. Whereas, low performance organizations are not, owing to their lack of such essential attributes ( Ironkwe \& Nwaiwu, 2018).

Performance is however, a difficult concept, in terms of definition and measurement. It has been defined as the end result of activity, and the appropriate measure selected to assess corporate performance is considered to depend on the type of organization to be evaluated and the objectives to be achieved through that evaluation (Al-Dalabih, 2018)

According to Encyclopedia of Business ( 2011:1) performance measures can be grouped into two basic types: those that relate to results (outputs or outcomes such as competitiveness or financial performance) and those that focus on the determinants of the results (inputs such as quality, flexibility, resource utilization, and innovation).

This suggests that performance measurement frameworks can be built around the concepts of results and determinants. Al-Dalabih, (2018) on the other hand opines that performance measurement systems are considered information systems that are used to evaluate both individual and organizational performance. Until recently, companies concentrated on the use of financial performance measures as the foundation of performance measurement and evaluation purposes. 
Journal DOI: www.doi.org/10.46654/ij.24889849

Article DOI: www.doi.org/10.46654/ij.24889849.s76161

According to Manehdot (2019) in business management, financial ratios are usually one of the indicators used to evaluate a firm's performance. Generally, the financial information of a company's business operations will be reported in the yearly financial statements, and a financial ratio simply constitutes one item divided by another in the financial statement. Financial ratios can be viewed as a preliminary reference for the analysis of the business performance. This agrees with Saeidi (2014) assertion that "ratios relate one set of values to another, with the resulting quotient serving as a measure, a standard or a norm by which performance is judged."

Traditionally, the measurement of a firm's performance usually employs the financial ratio method, because it provides a simple description about the firm's financial performance in comparison with previous periods and helps to improve its performance of management. According to Patal (2015) the measures of firm performance are usually ratios fashioned from financial statements or stock market prices, such as industry-adjusted operating margins or stock market returns.

Dandago and Rafoi (2014) maintain that there are two aspects of a company's financial performance of interest to investors. First, its financial performance may be assessed by reference to its ability to generate profit. This agrees with Ratal (2015) assertion that it is assumed that profit maximization causes the efficient allocation of resources under the competitive market conditions, and profit is considered as the most appropriate measure of a firm's performance. Esmeroy (2016) also assert that the key measure of a company's financial performance is its profitability. Thus, ratios of financial efficiency in this respect focus on the relationship between profit and sales and profit and assets employed. Second, the company's financial performance may be assessed in terms of the value of its shares to investors. In this way, ratios of financial performance focus on earnings per share, dividend yield and price/ earnings ratios. The ratios used to measure the overall profit performance of a firm are termed profitability ratios. Ratal (2015) and Esmerog (2016) maintains that profitability ratios are determined on the basis of either sales or investment.

\section{Accounting Information Quality}

The main objectives of information quality is to provide information concerning economic entity, primarily financial in nature, useful for economic decision making (IASB 2008; Van Beest et al., 2009). Information quality provides information about the management's stewardship; the entity's assets, liabilities, equity, income and expenses (including gains and loses), contributions by and distributions to owners as well as cashflows (Hla \& Teru, 2015). This information is usually in the form of annual financial statements such as the statement of financial position; the income statement or statement of comprehensive income; statement of cash flows and statement of changes in equity as well as notes to the accounts (IASB, 2008, 2010). To enhance reliability and confidence in the minds of the users, these reports are subjected to scrutiny by external auditors. This study will anchor on stakeholders' theory.

\section{Empirical Review}

There are theoretical and empirical evidence that examined the effect, influence, association and relationship between accounting information quality and financial performance and revealed mixed and inconclusive findings. Hout (2019) empirically studied the relationship between quality of accounting information and financial performance of quoted oil companies in Nigeria. Ex post facto research design and content analysis were adopted for 
Journal DOI: www.doi.org/10.46654/ij.24889849

the study. Secondary data were obtained from the quoted companies for the period 2014-2018 and the formulated hypotheses were tested by Pearson product moment correlation coefficient with the aid of statistical package for social sciences (SPSS) version 21. Their finding indicated significant relationship between quality of accounting information and financial performance of quoted oil companies in Nigeria. Therefore, it was recommended that accounting regulatory bodies should introduce strong quality of accounting information and reporting.

Maxwill and Wilson (2019) assessed accounting information quality and financial performance of oil marketing companies in Nigeria. Longitudinal study design was employed for the study. Secondary data was obtained from annual reports of the companies for 20042014. But multi-Binary logistic regression model was used to test the hypotheses. Their empirical finding indicated that total assets (firm size) as well as earnings per share (EPS) have positive and significant relationship with accounting information quality of oil marketing companies in Nigeria. It was also recommended that Nigerian stock exchange (NSE) should make it compulsory for the companies to set aside part of their profit for performance issues.

Wang and $\mathrm{Wu}$ (2018) assessed the relationship between accounting information quality and financial performance of quoted mining companies in Johannesburg, South Africa. Secondary data were obtained from annual report of the quoted companies from 2010-2014. The study adopted content analysis approach and also tested the formulated hypotheses by multiple regression analysis. The empirical studies fining showed a negative relationship between accounting information quality and financial performance of quoted mining companies. Conversely, the results showed positive relationship between accounting information quality and financial performance of the companies. It was recommended that quality information should be encouraged since it projects the generated financial returns.

Hubbard (2018) observes that while many frameworks have been developed for accounting information quality, few have received much general traction. Limited lights has actually been cost on financial performance by accounting information quality to date and so far it is unclear what effect it has actually had on organization strategies; practices and outcomes. Empirical works on effect of accounting information quality on financial performance reviewed here are research conducted by Burhan \& Rahmanti (2018) ascertained the effect of accounting information quality on company performance. Using a sample of thirty three companies listed on the Indonesian stock exchange during the period 2006-2009, the study uses linear regression model as well as multiple regression and their study shows that accounting information quality does not have an association with company performance, however, partially as only social performance disclosure influences the company performance. Burhan \& Rahmanti (2018) establishes a possible effect of accounting information quality on financial performance in Nigeria. Using a field survey methodology, a sample of 60 manufactory companies in Nigeria was studied. The study adopted a multiple regression analysis. This study revealed that the accounting information quality is significantly influence on financial performance. The paper concluded that, within the Nigerian setting at least, accounting information quality affects financial performance.

Thus, further going by the empirical studies reviewed, the webometric analysis are detailed below as thus: 
Journal DOI: www.doi.org/10.46654/ij.24889849

Article DOI: www.doi.org/10.46654/ij.24889849.s76161

Table 1: Webometric Assessment of Accounting Information Quality and Firm

Performance of Oil and Gas Companies.

\begin{tabular}{|c|c|c|c|c|}
\hline $\mathrm{S} / \mathrm{N}$ & Author's'/Year & Country & Journal Title & $\begin{array}{l}\text { Journal, Volume, Number \& } \\
\text { Pages. }\end{array}$ \\
\hline $\mathrm{i}$ & $\begin{array}{l}\text { Ahmad, } \\
\text { Siddiqui, \&, } \\
\text { Aboplsawh, } \\
(2020)\end{array}$ & Jordan & $\begin{array}{l}\text { Family SME's survival: The role of } \\
\text { owner. Family and Corporate } \\
\text { Social responsibility. }\end{array}$ & $\begin{array}{ll}\text { Journal f Small Business and } \\
\text { Enterprise } & \text { Development, } \\
27(2), 281-297 & \end{array}$ \\
\hline ii & $\begin{array}{l}\text { Al-Dalabih, } \\
\text { (2018) }\end{array}$ & Jordan & $\begin{array}{l}\text { The impact of the use of accounting } \\
\text { information system on the quality } \\
\text { of financial data. }\end{array}$ & $\begin{array}{l}\text { International } \\
\text { Research, 11(5), 143-158 }\end{array}$ \\
\hline iii & Budairi, (2017) & Iraqi & $\begin{array}{l}\text { The effect of quality of accounting } \\
\text { information on financial statements } \\
\text { on the decisions of its users, an } \\
\text { applied study in a group of Iraqi } \\
\text { companies. }\end{array}$ & $\begin{array}{l}\text { Al-Ghari Journal of Economic } \\
\text { and Administrative Sciences } \\
14(1), 355-388\end{array}$ \\
\hline iv & $\begin{array}{l}\text { Denos, Holt, } \\
\text { \& Imholf, } \\
\text { (2019) }\end{array}$ & UK & $\begin{array}{l}\text { The use of accounting information } \\
\text { in bank lending decisions }\end{array}$ & $\begin{array}{l}\text { Accounting, Organizations and } \\
\text { Society, 14(3), 235-246 }\end{array}$ \\
\hline $\mathrm{V}$ & $\begin{array}{l}\text { Odar, Kravic, } \\
\text { \& Jermon } \\
(2015) \text {. }\end{array}$ & Nigeria & $\begin{array}{l}\text { The role of management } \\
\text { Accounting system in decision- } \\
\text { making process: Evidence from a } \\
\text { post-transactions economy. }\end{array}$ & Economics, \\
\hline vi & $\begin{array}{l}\text { Obaidat } \\
\text { (2017) }\end{array}$ & Jordan & $\begin{array}{l}\text { Accounting information qualitative } \\
\text { characteristics gap: Evidence from } \\
\text { Jordan }\end{array}$ & $\begin{array}{l}\text { International Management } \\
\text { Review, 3(2),26-32 }\end{array}$ \\
\hline vii & $\begin{array}{l}\text { Palazuelos, } \\
\text { Crespo, \& } \\
\text { Delcorte, } \\
(2017)\end{array}$ & UK. & $\begin{array}{l}\text { Accounting information and trust as } \\
\text { determinants of credit granting to } \\
\text { SMEs: The role of external audit. }\end{array}$ & $\begin{array}{l}\text { Small Business Economics, } \\
51(4), 861-877\end{array}$ \\
\hline viii & Kashif, (2018) & Asia & $\begin{array}{l}\text { Impact of Accounting Information } \\
\text { system on the financial } \\
\text { performance of selected FMCG } \\
\text { companies. }\end{array}$ & $\begin{array}{l}\text { Asian Journal of Allied } \\
\text { Sciences and Technology, } \\
2(3), 8-17\end{array}$ \\
\hline ix & Rehab, (2018) & Nigeria & $\begin{array}{lrr}\text { The impact of Accounting } \\
\text { information } & \text { systems } & \text { on } \\
\text { organizational performance. } & \text { The } \\
\text { context of Saudi's SMEs. }\end{array}$ & $\begin{array}{l}\text { International Review of } \\
\text { Management and Marketing, } \\
8(2), 69-73 \text {. }\end{array}$ \\
\hline $\mathrm{x}$ & $\begin{array}{l}\text { Farah, } \\
\text { Farrukh, \& } \\
\text { Faizan, (2016) }\end{array}$ & Pakistan & $\begin{array}{l}\text { Financial performance of firms: } \\
\text { Evidence from Pakistan Cement } \\
\text { industry }\end{array}$ & $\begin{array}{l}\text { Journal of Teaching and } \\
\text { Education, 5(1),81-94 }\end{array}$ \\
\hline $\mathrm{xi}$ & $\begin{array}{l}\text { Mitchell, } \\
\text { Biykan, } \\
\text { Oniken, \& } \\
\text { Fiedler, (2017) }\end{array}$ & UK & $\begin{array}{l}\text { The contingency model: Criticism } \\
\text { and suggestion }\end{array}$ & $\begin{array}{l}\text { Academy of Management } \\
\text { Journal, 13(3),1-23 }\end{array}$ \\
\hline xii & $\begin{array}{l}\text { Ironkwe \& } \\
\text { Nwaiwu, } \\
(2018)\end{array}$ & Nigeria & $\begin{array}{l}\text { Accounting information system on } \\
\text { financial and Non-financial } \\
\text { measures of companies in Nigeria. }\end{array}$ & $\begin{array}{lrr}\text { International Journal of } \\
\text { Advanced } & \text { Academic } \\
\text { Research/Business } & \\
\end{array}$ \\
\hline
\end{tabular}


Journal DOI: www.doi.org/10.46654/ij.24889849

Article DOI: www.doi.org/10.46654/ij.24889849.s76161

\begin{tabular}{|c|c|c|c|c|}
\hline & & & & $\begin{array}{l}\text { Development \& Management, } \\
4(2), 39-55\end{array}$ \\
\hline xiii & $\begin{array}{l}\text { Akanbi, \& } \\
\text { Adewoye, } \\
(2018)\end{array}$ & Nigeria & $\begin{array}{l}\text { Effects of Accounting Information } \\
\text { System Adoption on the financial } \\
\text { performance of central Bank in } \\
\text { Nigeria. }\end{array}$ & $\begin{array}{l}\text { Journal of Accounting \& } \\
\text { Marketing, } 1(6), 1-6\end{array}$ \\
\hline xiv & $\begin{array}{l}\text { Alnajjar, } \\
(2017)\end{array}$ & Nigeria & $\begin{array}{l}\text { Impact of Accounting information } \\
\text { system on organizational } \\
\text { performance: A study of SME's in } \\
\text { the UAE. }\end{array}$ & $\begin{array}{l}\text { Journal of Accounting } \& \\
\text { Finance, } 3(1), 20-35\end{array}$ \\
\hline $\mathrm{XV}$ & Raed, (2017) & Jordan & $\begin{array}{l}\text { The impact of computerized } \\
\text { accounting information system on } \\
\text { management performance in public } \\
\text { sector in Nigeria: problem \& } \\
\text { Prospects. }\end{array}$ & $\begin{array}{l}\text { International Journal of } \\
\text { Multidisciplinary Research and } \\
\text { Development, 4(12),80-83 }\end{array}$ \\
\hline xvi & $\begin{array}{l}\text { Tera, } \\
\text { IdoNdeyati, } \\
(2017)\end{array}$ & India & $\begin{array}{l}\text { A review of the impact of } \\
\text { accounting information system for } \\
\text { effective internal control on firm } \\
\text { performance. }\end{array}$ & $\begin{array}{l}\text { Indian Journal of Finance and } \\
\text { Banking, 1(2),52-59 }\end{array}$ \\
\hline xvii & $\begin{array}{l}\text { Akanbi, \& } \\
\text { Adewoye, } \\
(2018)\end{array}$ & Nigeria & $\begin{array}{l}\text { Effects of Accounting information } \\
\text { system adoption on the financial } \\
\text { performance of commercial bank in } \\
\text { Nigeria. }\end{array}$ & $\begin{array}{l}\text { Journal of Accounting \& } \\
\text { Marketing, } 1(6), 1-6\end{array}$ \\
\hline xviii & $\begin{array}{l}\text { Borhan, \& } \\
\text { Nofees, (2018) }\end{array}$ & Jordan & $\begin{array}{l}\text { Effects of accounting information } \\
\text { system on financial performance: A } \\
\text { study of selected real estate } \\
\text { companies in Jordan. }\end{array}$ & $\begin{array}{l}\text { India Technical Research } \\
\text { Organization, 5(1),41-50 }\end{array}$ \\
\hline xix & Isa, $(2017$ & Nigeria & $\begin{array}{l}\text { The impact of computerized } \\
\text { accounting information system on } \\
\text { management performance in public } \\
\text { sector in Nigeria: Problem and } \\
\text { Prospects. }\end{array}$ & $\begin{array}{l}\text { International Journal of } \\
\text { Multidisciplinary Research and } \\
\text { Development, 4(1),80-83 }\end{array}$ \\
\hline $\mathrm{xxi}$ & Khan, (2017) & Nigeria & $\begin{array}{l}\text { Impact of Accounting information } \\
\text { system on the organizational } \\
\text { performance: A case study of } \\
\text { Procter and Gamble. }\end{array}$ & Star Research, 5(12),20-30 \\
\hline xxii & $\begin{array}{l}\text { Nizor, Ahmad, } \\
\& \\
\text { Mohamad,(201 } \\
6 \text { ) }\end{array}$ & $\begin{array}{l}\text { United } \\
\text { Arab } \\
\text { Emirates }\end{array}$ & $\begin{array}{l}\text { Evaluate of accounting information } \\
\text { systems in meeting the } \\
\text { requirements of financial and } \\
\text { managerial performance. Field } \\
\text { study in the United Arab Emirates } \\
\text { private Hospitals. }\end{array}$ & $\begin{array}{l}\text { International Journal } \begin{array}{r}\text { of } \\
\text { Humanities and } \\
\text { Science, 6(4), 170-196 }\end{array} \\
\text { Social } \\
\end{array}$ \\
\hline xxiii & $\begin{array}{l}\text { Akesinro, \& } \\
\text { Adetoso, } \\
(2016) .\end{array}$ & Nigeria & $\begin{array}{l}\text { The effects of computerized } \\
\text { accounting system on the } \\
\text { performance of banks in Nigeria. }\end{array}$ & $\begin{array}{lr}\text { Journal of } & \text { Economics and } \\
\text { Sustainable } & \text { Development, } \\
7(14), 76-82 & \\
\end{array}$ \\
\hline xxiv & $\begin{array}{l}\text { Ali, Bakar, \& } \\
\text { Omar, (2016) }\end{array}$ & Jordan & $\begin{array}{l}\text { The critical success factors of } \\
\text { Accounting Information System } \\
\text { (AIS) and its impact on }\end{array}$ & 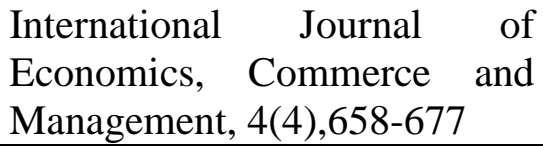 \\
\hline
\end{tabular}


Journal DOI: www.doi.org/10.46654/ij.24889849

Article DOI: www.doi.org/10.46654/ij.24889849.s76161

\begin{tabular}{|c|c|c|c|c|}
\hline & & & $\begin{array}{l}\text { organizational performance of } \\
\text { Jordan commercial banks }\end{array}$ & \\
\hline $\mathrm{xxV}$ & $\begin{array}{l}\text { Esmeray, } \\
(2016)\end{array}$ & Turkey & $\begin{array}{l}\text { The impact of accounting } \\
\text { information systems in firm } \\
\text { performance: Empirical evidence in } \\
\text { Turkish small and medium sized } \\
\text { enterprises. }\end{array}$ & $\begin{array}{l}\text { International Review of } \\
\text { Management and Marketing, } \\
6(2), 233-236\end{array}$ \\
\hline xxvi & $\begin{array}{l}\text { Mahdi, } \\
\text { Mahmond, } \\
\text { Mostafa, \& } \\
\text { Ebadohollah, } \\
\text { (2015) }\end{array}$ & Iran & $\begin{array}{l}\text { The effect of implementation of } \\
\text { accounting information system on } \\
\text { efficiency, profitability and } \\
\text { productivity of SMEs in Iran. }\end{array}$ & $\begin{array}{l}\text { Banks and Bank Systems, } \\
10(3), 79-86\end{array}$ \\
\hline xxvii & Taiwo, (2016) & Nigeria & $\begin{array}{l}\text { Effect of ICT on accounting } \\
\text { information systems }\end{array}$ & $\begin{array}{l}\text { European Journal of Business } \\
\text { and Social Sciences, 5(2),1-15 }\end{array}$ \\
\hline xxix & $\begin{array}{l}\text { Dekeng, \& } \\
\text { Prabowo, } \\
(2015)\end{array}$ & Nigeria & $\begin{array}{l}\text { Accounting information system } \\
\text { alignment and Smes performance. } \\
\text { A literature Review. }\end{array}$ & $\begin{array}{lcc}\text { International } & \text { Journal } & \text { of } \\
\text { Management, } & \text { Economics } & \& \\
\text { Social Sciences, } 4(2), 58-70 & \end{array}$ \\
\hline $\mathrm{xxx}$ & $\begin{array}{l}\text { Hla, \& Teru, } \\
(2015\end{array}$ & India & $\begin{array}{lcr}\text { Efficiency } & \text { of } & \text { accounting } \\
\text { information } & \text { system } & \text { and } \\
\text { performance } & \text { measures: Literature } \\
\text { Review } & & \end{array}$ & $\begin{array}{l}\text { International Journal of } \\
\text { Multidisciplinary and Current } \\
\text { Research, 3(3),976-984 }\end{array}$ \\
\hline xxxi & Patal, (2015 & Nigeria & $\begin{array}{l}\text { Effects of accounting information } \\
\text { system on organizational } \\
\text { profitability. }\end{array}$ & $\begin{array}{l}\text { International Journal of } \\
\text { Research and Analytical } \\
\text { Reviews, 2(1),72-77 }\end{array}$ \\
\hline xxxii & Saeidi (2014) & India & $\begin{array}{l}\text { The impact of accounting } \\
\text { information system on financial } \\
\text { performance. A case study of TCS } \\
\text { India. }\end{array}$ & $\begin{array}{l}\text { Indian Journal of Fundamental } \\
\text { and Applied Life Sciences, } \\
4(4), 412-417\end{array}$ \\
\hline $\begin{array}{l}\text { xxxii } \\
\text { i }\end{array}$ & $\begin{array}{l}\text { Eb, Pretorious, } \\
\text { \& Zuva, } \\
(2013)\end{array}$ & Nigeria & $\begin{array}{l}\text { The role of accounting information } \\
\text { system in accounting firm. }\end{array}$ & $\begin{array}{l}\text { International Journal of } \\
\text { Accounting, } \quad \text { Advanced } \\
\text { Computer Research, 1(2),21- } \\
31\end{array}$ \\
\hline $\begin{array}{l}\mathrm{xxxi} \\
\mathrm{v}\end{array}$ & $\begin{array}{l}\text { Manchdot, } \\
\text { (2019) }\end{array}$ & UK & $\begin{array}{l}\text { A review of determinants } \\
\text { Accounting information system } \\
\text { adoption. }\end{array}$ & $\begin{array}{l}\text { Science Journal of Business } \\
\text { Management, } 7(1), 17-22\end{array}$ \\
\hline xxxv & $\begin{array}{l}\text { Dandago, } \\
\text { Rafai, (2014) }\end{array}$ & Nigeria & $\begin{array}{l}\text { Information technology and } \\
\text { accounting system in the Nigerian } \\
\text { banking industry. }\end{array}$ & $\begin{array}{l}\text { Asian Economic and Financial } \\
\text { Review, 2(10),1-9 }\end{array}$ \\
\hline $\begin{array}{l}x \times x V \\
i\end{array}$ & Samer,(2016) & Jordan & $\begin{array}{l}\text { The impact of the effectiveness of } \\
\text { accounting information systems on } \\
\text { operational performance in public } \\
\text { listed industrial companies in } \\
\text { Jordan. }\end{array}$ & $\begin{array}{l}\text { Journal of Social Sciences, } \\
5(3), 265-276\end{array}$ \\
\hline $\mathrm{xxxV}$ & Yaser, Mina, & Nigeria & The impact of the effectiveness of & Asian Eco \\
\hline
\end{tabular}


Journal DOI: www.doi.org/10.46654/ij.24889849

Article DOI: www.doi.org/10.46654/ij.24889849.s76161

\begin{tabular}{|l|l|l|l|l|}
\hline ii & \& Nor, (2014) & & $\begin{array}{l}\text { accounting information system in } \\
\text { Nigerian banking industries. }\end{array}$ & Review, 4(5), 655-670 \\
\hline
\end{tabular}

\section{Research question and Hypothesis Development Context}

This study empirically seeks to explore the relationship between accounting information quality and quoted financial performance of oil and gas companies in Nigeria. Specifically, the study provides answer to the following research question (RQ).

RQ1: What is the nature of relationship between accounting information quality and firm performance of quoted oil and gas companies in Nigeria?

However, the above research question generated two hypotheses stated in the null form as thus:

$\mathrm{H}_{01}$ : There is no significant relationship between audit lag and earnings per share of quoted oil and gas companies in Nigeria.

$\mathrm{H}_{02}$ : Disclosure quality does not relate to earnings per share of quoted oil and gas companies in Nigeria.

\section{Research Methods:}

This section shows that research methods adopted to investigate the long run equilibrating relationship and short run dynamics in the variables if any to achieve the set objectives of the study. The research design applied is causal-comparative design which attempts to identify the cause-effect relationship between two or more variables. Time series data regarding the variable were sourced from the financial statements of the sampled quoted oil and gas companies, central bank of Nigeria statistic bulletin, annual central bank of Nigeria reports, National Bureau of statistics and Federal Inland Revenue Service.

However, from the secondary data collected, we utilized ordinary least square (OLS) of multivariate regression based Autoregressive Distributed Lag, Augmented Dickey-Fuller unit root test, co-integration test, Error Correction model, serial correlation and Heteroskedasticity test, lag order selection criteria and Granger causality test.

\section{Model Specification}

EPS $_{\mathrm{t}}=\quad \int(\mathrm{ALG}, \mathrm{DQT})-$
Transforming equation 1 into mathematical form as thus
EPS $_{\mathrm{t}}=\quad \beta_{1} \mathrm{ALG}_{\mathrm{t}}+\beta_{2} \mathrm{DOT}_{\mathrm{t}} \quad-$

\section{Apriori Expectation}

From the foregoing, it is expected that accounting information quality will significantly relate to firm performance of quoted oil and gas companies in Nigeria. The apriori expectation of this empirical study is stated as follows: $\lambda_{1}-\lambda_{2}>0$ 
Journal DOI: www.doi.org/10.46654/ij.24889849

Article DOI: www.doi.org/10.46654/ij.24889849.s76161

\section{Empirical Results and Discussion}

This section interprets the apriori expectation of the econometric results obtained.

\section{Pooled Effects regression}

To evaluate for joint influence of employed variables on the criterion, the table above which represents the pooled effect shows that;

\section{Table 2 Pooled Effects Regression Output.}

Criterion variable: $\mathrm{D}(\mathrm{EPS})$

Method: Panel Least Squares

Date: 07/09/20 Time: 01:24

Sample: 20092018

Periods included: 10

Cross-sections included: 4

Total panel (balanced) observations: 40

\begin{tabular}{lrlrc}
\hline \hline \multicolumn{1}{c}{ Variable } & Coefficient & \multicolumn{1}{c}{ Std. Error } & t-Statistic & Prob. \\
\hline \hline \multicolumn{1}{c}{ C } & 9002912. & 4342048. & 2.073425 & 0.0407 \\
D(ALG) & -3.847755 & 3.032814 & -1.268708 & 0.2075 \\
D(DQT) & 3.597355 & 4.493480 & 0.800572 & 0.4253 \\
\hline \hline R-squared & 0.452563 & Mean dependent var & 12021453 \\
Adjusted R-squared & 0.418666 & S.D. dependent var & 27231462 \\
S.E. of regression & 25564733 & Akaike info criterion & 36.99777 \\
Sum squared resid & $6.54 \mathrm{E}+16$ & Schwarz criterion & 37.12415 \\
Log likelihood & -1937.383 & Hannan-Quinn criter. & 37.04898 \\
F-statistic & 4.500728 & Durbin-Watson stat & 0.579880 \\
Prob(F-statistic) & 0.002194 & & \\
\hline \hline
\end{tabular}

Based on the above output in Table 2, it can be easily deduced that Audit Reporting Lag (ALG) showed an adverse/negative coefficient of -3.846355 , while no variable is found to be significant. The fundamental problem of this model lies from the fact that employed predictor variables jointly account for 45.26 percent of variations in the criterion variables. The second problem with this regression type (pooled effect) is the fact that, it fails to evaluate individuality or heterogeneous tendencies that exist in each of our employed companies. Since all companies cannot be the same, we do not accept this result. 
Journal DOI: www.doi.org/10.46654/ij.24889849

Article DOI: www.doi.org/10.46654/ij.24889849.s76161

\section{Fixed Effect Regressions}

To deal with the issues of heterogeneity bias, the fixed effect is carried out as follows:

Table 3 Fixed Effects Regression Output.

Criterion variable: $\mathrm{D}(\mathrm{EPS})$

Method: Panel Least Squares

Date: 07/09/20 Time: 00:55

Sample: 20092018

Periods included: 10

Cross-sections included: 4

Total panel (balanced) observations: 40

\begin{tabular}{|c|c|c|c|c|}
\hline Variable & Coefficient & Std. Error & t-Statistic & Prob. \\
\hline $\mathrm{C}$ & 36319009 & 5248544. & 6.919826 & 0.0000 \\
\hline $\mathrm{D}(\mathrm{ALG})$ & -7.160194 & 1.571511 & -4.556249 & 0.0000 \\
\hline D(DQT) & -6.671449 & 2.237966 & -2.981032 & 0.0037 \\
\hline \multicolumn{5}{|c|}{ Effects Specification } \\
\hline \multicolumn{5}{|c|}{ Cross-section fixed (dummy variables) } \\
\hline R-squared & 0.886369 & \multicolumn{2}{|c|}{ Mean dependent var } & 12021453 \\
\hline Adjusted R-squared & 0.862586 & \multicolumn{2}{|c|}{ S.D. dependent var } & 27231462 \\
\hline S.E. of regression & 10094552 & \multicolumn{2}{|c|}{ Akaike info criterion } & 35.25518 \\
\hline Sum squared resid & $8.76 \mathrm{E}+15$ & \multicolumn{2}{|c|}{ Schwarz criterion } & 35.73542 \\
\hline Log likelihood & -1831.897 & \multicolumn{2}{|c|}{ Hannan-Quinn criter. } & 35.44978 \\
\hline F-statistic & 37.26861 & \multicolumn{2}{|c|}{ Durbin-Watson stat } & 1.814343 \\
\hline $\operatorname{Prob}($ F-statistic) & 0.000000 & & & \\
\hline
\end{tabular}

The coefficient significance level shows that all forms of Accounting Information Quality dimensions by firms have significant tendencies to stimulate earnings per share of employed firms as they Possess probability level way below the 5\% significance level. Audit Reporting Lag (ALG) shows a negative coefficient. Despite the dominance of this model (Fixed effect or LSDV model) which allows for heterogeneous factors and individuality amongst employed variables except for the intercept/constant not varying overtime. We further proceed to the Random effect to check for the common mean value of employed variables and their influence on the criterion variable. 
Journal DOI: www.doi.org/10.46654/ij.24889849

Article DOI: www.doi.org/10.46654/ij.24889849.s76161

Random Effects Model

Table 4 Random Effects Regression Output.

Criterion variable: $\mathrm{D}(\mathrm{EPS})$

Method: Panel EGLS (Cross-section random effects)

Date: 07/09/20 Time: 00:55

Sample: 20092018

Periods included: 10

Cross-sections included: 4

Total panel (balanced) observations: 40

Swamy and Arora estimator of component variances

\begin{tabular}{|c|c|c|c|c|}
\hline Variable & Coefficient & Std. Error & $\mathrm{t}$-Statistic & Prob. \\
\hline $\mathrm{C}$ & 12910484 & 6149396. & 2.099472 & 0.0383 \\
\hline $\mathrm{D}(\mathrm{ALG})$ & -2.625410 & 1.352060 & -1.941785 & 0.0550 \\
\hline $\mathrm{D}(\mathrm{DQT})$ & 0.365332 & 1.944670 & 0.187863 & 0.8514 \\
\hline \multicolumn{5}{|c|}{ Effects Specification } \\
\hline & & & S.D. & Rho \\
\hline Cross-section random & & & 19309520 & 0.7854 \\
\hline Idiosyncratic random & & & 10094552 & 0.2146 \\
\hline \multicolumn{5}{|c|}{ Weighted Statistics } \\
\hline R-squared & 0.291183 & \multirow{5}{*}{\multicolumn{2}{|c|}{$\begin{array}{l}\text { Mean dependent var } \\
\text { S.D. dependent var } \\
\text { Sum squared resid } \\
\text { Durbin-Watson stat }\end{array}$}} & 2330274 \\
\hline Adjusted R-squared & 0.262831 & & & 14832776 \\
\hline S.E. of regression & 12735209 & & & $1.62 \mathrm{E}+16$ \\
\hline F-statistic & 10.27005 & & & 1.052149 \\
\hline \multirow[t]{2}{*}{ Prob(F-statistic) } & 0.000001 & & & \\
\hline & \multicolumn{3}{|c|}{ Unweighted Statistics } & \\
\hline R-squared & -0.732719 & Mean depende & var & 12021453 \\
\hline Sum squared resid & $1.34 \mathrm{E}+17$ & Durbin-Watso & & 0.127699 \\
\hline
\end{tabular}

The random effect above shows a lower predictive ability of employed predictor variables. This is evident as the R-square of 0.291183 shows that employed predictor variables jointly account for only 29.12 percent of variation in Return on Equity of oil companies (EPS). The idiosyncratic random Rho shows 0.2146 which is very low and as such shows a disconnect between employed variables and also their inherent residuals. In this effect, Audit Reporting Lag (ALG) similarly shows a negative coefficients, but no variable shows significant influence on earnings per share.

\section{Diagnostic test}

The need therefore arises to determine which of the model is most efficient i.e. whether the pooled, random or fixed effect.

\section{Likelihood Ratio Test}

To compare the pooled regression model with the fixed effects model. The null hypothesis favors the pooled model i.e. Unobserved sectional differences are not significant. 
Journal DOI: www.doi.org/10.46654/ij.24889849

Article DOI: www.doi.org/10.46654/ij.24889849.s76161

Table 5 Likelihood ratio test output

Redundant Fixed Effects Tests

Equation: Untitled

Test cross-section fixed effects

\begin{tabular}{lrrr}
\hline \hline Effects Test & Statistic & d.f. & Prob. \\
\hline \hline Cross-section F & 39.669263 & $(14,86)$ & 0.0000 \\
Cross-section Chi-square & 210.972165 & 14 & 0.0000 \\
\hline \hline
\end{tabular}

Cross-section fixed effects test equation:

Criterion variable: $\mathrm{D}(\mathrm{EPS})$

Method: Panel Least Squares

Date: 07/09/20 Time: 00:57

Sample: 20092018

Periods included: 10

Cross-sections included: 4

Total panel (balanced) observations: 40

\begin{tabular}{lrlrr}
\hline \hline \multicolumn{1}{c}{ Variable } & Coefficient & Std. Error & t-Statistic & Prob. \\
\hline \multicolumn{1}{c}{ C } & 9002912. & 4342048. & 2.073425 & 0.0407 \\
D(ALG) & -3.847755 & 3.032814 & -1.268708 & 0.2075 \\
D(DQT) & 3.597355 & 4.493480 & 0.800572 & 0.4253 \\
\hline \hline R-squared & 0.152563 & Mean dependent var & 12021453 \\
Adjusted R-squared & 0.118666 & S.D. dependent var & 27231462 \\
S.E. of regression & 25564733 & Akaike info criterion & 36.99777 \\
Sum squared resid & $6.54 \mathrm{E}+16$ & Schwarz criterion & 37.12415 \\
Log likelihood & -1937.383 & Hannan-Quinn criter. & 37.04898 \\
F-statistic & 4.500728 & Durbin-Watson stat & 0.579880 \\
Prob(F-statistic) & 0.002194 & & \\
\hline \hline
\end{tabular}

The above likelihood ratio test which shows the predominance between the pooled and fixed effect is seen to show a cross-section F-statistics of 39.669263 at a probability level of 0.0000 which is seen to be below the 0.05 significance level. This leads to the rejection of the null hypothesis (the null hypothesis supports the pooled model). The alternate hypothesis which is accepted favors the fixed effect. The study therefore upholds the fixed effect over the pooled effect. We therefore proceed to evaluate the better model between the fixed and random model.

\section{Hausman Specification Test}

To compare the random effect model with the fixed test model. The null hypothesis favours the random effects model i.e. $z_{i}$ are uncorrelated with the explanatory variables (Its null hypothesis is that the random effects model is appropriate while the alternative hypothesis is the fixed effects model is appropriate). 
Journal DOI: www.doi.org/10.46654/ij.24889849

Article DOI: www.doi.org/10.46654/ij.24889849.s76161

Table 6 Hausman Specification Test output

Correlated Random Effects - Hausman Test

Equation: Untitled

Test cross-section random effects

\begin{tabular}{lccc}
\hline \hline Test Summary & $\begin{array}{c}\text { Chi-Sq. } \\
\text { Statistic }\end{array}$ & Chi-Sq. d.f. & Prob. \\
\hline \hline Cross-section random & 62.161515 & 4 & 0.0000 \\
\hline \hline
\end{tabular}

Cross-section random effects test comparisons:

\begin{tabular}{ccccc} 
Variable & Fixed & Random & Var(Diff.) & Prob. \\
\hline \hline D(ALG) & -7.160194 & -2.625410 & 0.641579 & 0.0000 \\
D(DQT) & -6.671449 & 0.365332 & 1.226751 & 0.0000 \\
\hline \hline
\end{tabular}

Cross-section random effects test equation:

Criterion variable: $\mathrm{D}(\mathrm{EPS})$

Method: Panel Least Squares

Date: 07/09/20 Time: 00:58

Sample: 20092018

Periods included: 10

Cross-sections included: 4

Total panel (balanced) observations: 40

\begin{tabular}{|c|c|c|c|c|}
\hline Variable & Coefficient & Std. Error & t-Statistic & Prob. \\
\hline & 36319009 & 5248544. & 6.919826 & 0.0000 \\
\hline $\mathrm{D}(\mathrm{ALG})$ & -7.160194 & 1.571511 & -4.556249 & 0.0000 \\
\hline D(DQT) & -6.671449 & 2.237966 & -2.981032 & 0.0037 \\
\hline \multicolumn{5}{|c|}{ Effects Specification } \\
\hline \multicolumn{5}{|c|}{ Cross-section fixed (dummy variables) } \\
\hline R-squared & 0.886369 & \multicolumn{2}{|c|}{ Mean dependent var } & 12021453 \\
\hline Adjusted R-squared & 0.862586 & \multicolumn{2}{|c|}{ S.D. dependent var } & 27231462 \\
\hline S.E. of regression & 10094552 & \multicolumn{2}{|c|}{ Akaike info criterion } & 35.25518 \\
\hline Sum squared resid & $8.76 \mathrm{E}+15$ & \multicolumn{2}{|c|}{ Schwarz criterion } & 35.73542 \\
\hline Log likelihood & -1831.897 & \multicolumn{2}{|c|}{ Hannan-Quinn criter. } & 35.44978 \\
\hline F-statistic & 37.26861 & \multicolumn{2}{|c|}{ Durbin-Watson stat } & 1.814343 \\
\hline Prob(F-statistic) & 0.000000 & & & \\
\hline
\end{tabular}

The Hausman specification test output via its cross section random chi square statistics of 62.161515 at a probability level of 0.0000 leads to the rejection of the null hypothesis (the null hypothesis supports the random effect). The alternate hypothesis thus upholds the effect of the fixed model. Therefore, the validity of empirical output of the fixed model stands and is binding on employed variables in the short run. 
Journal DOI: www.doi.org/10.46654/ij.24889849

Article DOI: www.doi.org/10.46654/ij.24889849.s76161

\section{Lagrange Multiplier Test}

To decide between the random effect and a simple OLS regression, we carry out the Lagrange multiplier test below;

\section{Table 7. Lagrange Multiplier Tests output}

Lagrange Multiplier Tests for Random Effects

Null hypotheses: No effects

Alternative hypotheses: Two-sided (Breusch-Pagan) and one-sided (all others) alternatives

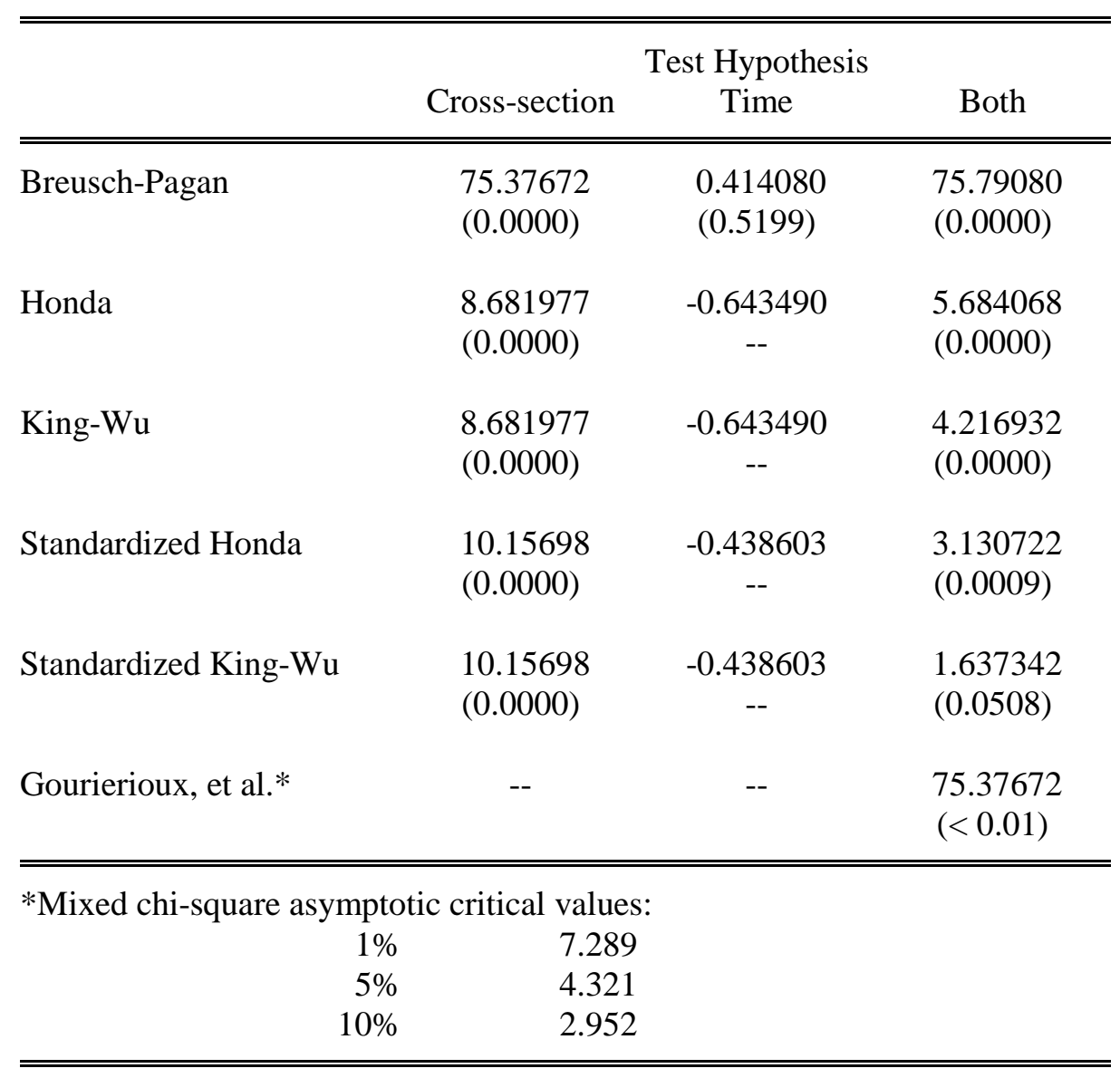

The above probability levels at all Lagrange types show probability level less than 0.05 , we therefore reject the null hypothesis. And conclude that random effect is more superior (which supports our even more superior fixed effect). This is evidence of significant differences across firms. Based on this finings, the study adopts the fixed effect.

\section{Panel Co-integration Test}

To evaluate for traces and entrails of long run relationship, the Kao residual co-integration test is carried out. 
Journal DOI: www.doi.org/10.46654/ij.24889849

Article DOI: www.doi.org/10.46654/ij.24889849.s76161

Table 8. Kao Residual Co-integration Test output

Kao Residual Cointegration Test

Series: D(EPS) D(ALG) D(DQT)

Date: 07/09/20 Time: 01:02

Sample: 20092018

Included observations: 40

Null Hypothesis: No cointegration

Trend assumption: No deterministic trend

Automatic lag length selection based on SIC with a max lag of 1

Newey-West automatic bandwidth selection and Bartlett kernel

\begin{tabular}{lll}
\hline \hline \multirow{2}{*}{ ADF } & t-Statistic & Prob. \\
\cline { 2 - 3 } \multicolumn{1}{c|}{ Residual variance } & -5.046418 & 0.0000 \\
\hline \hline HAC variance & $1.38 \mathrm{E}+14$ & \\
\hline \hline
\end{tabular}

Augmented Dickey-Fuller Test Equation

Criterion variable: $\mathrm{D}$ (RESID)

Method: Least Squares

Date: 07/09/20 Time: 01:02

Sample (adjusted): 20102018

Included observations: 36 after adjustments

\begin{tabular}{lrllr}
\hline \hline \multicolumn{1}{c}{ Variable } & Coefficient & Std. Error & t-Statistic & Prob. \\
\hline \hline \multicolumn{1}{c}{ RESID(-1) } & -0.957383 & 0.106700 & -8.972693 & 0.0000 \\
\hline \hline R-squared & 0.474657 & Mean dependent var & -294461.3 \\
Adjusted R-squared & 0.474657 & S.D. dependent var & 12439533 \\
S.E. of regression & 9016239. & Akaike info criterion & 34.87800 \\
Sum squared resid & $7.24 \mathrm{E}+15$ & Schwarz criterion & 34.90578 \\
Log likelihood & -1568.510 & Hannan-Quinn criter. & 34.88920 \\
Durbin-Watson stat & 2.105145 & & \\
\hline \hline
\end{tabular}

In light of long run relationship, the above Augmented Dickey Fuller t-statistics value of 5.046418 at a probability level of 0.000 which is less than the $5 \%$ significance level shows a great evidence in support of the existence of a long run relationship between employed variables. This shows that, there is evidence of similarities in trend between employed variable amidst variations and shocks in the immediate financial environment.

\section{Panel Error Correction Model}

To adjust for discrepancies between the long and short run equilibrium, the study carries out the error correction model as follows; 
Table 9. Error Correction Model Estimate Test output

Vector Error Correction Estimates

Date: 07/09/20 Time: 01:03

Sample (adjusted): 20092018

Included observations: 160 after adjustments

Standard errors in ( ) \& t-statistics in [ ]

\begin{tabular}{|c|c|c|c|}
\hline Cointegrating Eq: & CointEq1 & & \\
\hline EPS(-1) & 1.000000 & & \\
\hline ALG(-1) & $\begin{array}{r}-325.8053 \\
(19.3554) \\
{[-16.8328]}\end{array}$ & & \\
\hline DQT(-1) & $\begin{array}{c}497.0501 \\
(28.0059) \\
{[17.7481]}\end{array}$ & & \\
\hline $\mathrm{C}$ & -69516438 & & \\
\hline Error Correction: & $\mathrm{D}(\mathrm{EPS})$ & $\mathrm{D}(\mathrm{ALG})$ & $\mathrm{D}(\mathrm{DQT})$ \\
\hline CointEq1 & $\begin{array}{r}-0.202982 \\
(0.08759) \\
{[-2.31752]}\end{array}$ & $\begin{array}{r}-0.000530 \\
(0.00026) \\
{[-2.01938]}\end{array}$ & $\begin{array}{r}-0.001399 \\
(0.00020) \\
{[-6.85389]}\end{array}$ \\
\hline $\mathrm{D}(\mathrm{EPS}(-1))$ & $\begin{array}{r}-0.738032 \\
(0.17085) \\
{[-4.31983]}\end{array}$ & $\begin{array}{r}-0.006313 \\
(0.00193) \\
{[-3.27178]}\end{array}$ & $\begin{array}{r}-0.004454 \\
(0.00150) \\
{[-2.96761]}\end{array}$ \\
\hline $\mathrm{D}(\mathrm{EPS}(-2))$ & $\begin{array}{r}-0.137165 \\
(0.19614) \\
{[-0.69931]}\end{array}$ & $\begin{array}{r}-0.000334 \\
(0.00222) \\
{[-0.15080]}\end{array}$ & $\begin{array}{r}-0.001381 \\
(0.00172) \\
{[-0.80163]}\end{array}$ \\
\hline $\mathrm{D}(\mathrm{ALG}(-1))$ & $\begin{array}{c}4.214196 \\
(7.75551) \\
{[0.54338]}\end{array}$ & $\begin{array}{r}-0.202982 \\
(0.08759) \\
{[-2.31752]}\end{array}$ & $\begin{array}{r}-0.296102 \\
(0.06813) \\
{[-4.34641]}\end{array}$ \\
\hline $\mathrm{D}(\mathrm{ALG}(-2))$ & $\begin{array}{r}9.217044 \\
(7.18244) \\
{[1.28327]}\end{array}$ & $\begin{array}{r}-0.007748 \\
(0.08111) \\
{[-0.09552]}\end{array}$ & $\begin{array}{c}0.112215 \\
(0.06309) \\
{[1.77860]}\end{array}$ \\
\hline $\mathrm{D}(\mathrm{DQT}(-1))$ & $\begin{array}{r}-10.16654 \\
(4.12502) \\
{[-2.46461]}\end{array}$ & $\begin{array}{c}0.099429 \\
(0.04659) \\
{[2.13433]}\end{array}$ & $\begin{array}{c}0.173482 \\
(0.03623) \\
{[4.78772]}\end{array}$ \\
\hline $\mathrm{D}(\mathrm{DQT}(-2))$ & $\begin{array}{r}-6.978944 \\
(4.63977) \\
{[-1.50416]}\end{array}$ & $\begin{array}{c}0.113406 \\
(0.05240) \\
{[2.16429]}\end{array}$ & $\begin{array}{r}-0.061580 \\
(0.04076) \\
{[-1.51093]}\end{array}$ \\
\hline $\mathrm{C}$ & 1960109. & $\begin{array}{l}-76127.18 \\
19\end{array}$ & -111065.8 \\
\hline
\end{tabular}


Journal DOI: www.doi.org/10.46654/ij.24889849

Article DOI: www.doi.org/10.46654/ij.24889849.s76161

\begin{tabular}{lrrr}
\hline \hline & $(2708725)$ & $(30590.6)$ & $(23793.9)$ \\
{$[0.72363]$} & {$[-2.48858]$} & {$[-4.66783]$} \\
\hline \hline R-squared & 0.650621 & 0.677967 & 0.816256 \\
Adj. R-squared & 0.501805 & 0.581251 & 0.797064 \\
Sum sq. resids & $9.18 \mathrm{E}+15$ & $1.17 \mathrm{E}+12$ & $7.08 \mathrm{E}+11$ \\
S.E. equation & 13828578 & 156171.2 & 121472.5 \\
F-statistic & 2.356069 & 5.975926 & 47.74297 \\
Log likelihood & -1064.977 & -795.9645 & -780.8886 \\
Akaike AIC & 35.89923 & 26.93215 & 26.42962 \\
Schwarz SC & 36.31810 & 27.35102 & 26.84849 \\
Mean dependent & -645097.9 & -92092.00 & -116886.8 \\
S.D. dependent & 15478290 & 216831.4 & 378612.2 \\
\hline \hline Determinant resid covariance (dof adj.) & $1.36 \mathrm{E}+59$ & \\
Determinant resid covariance & & $4.45 \mathrm{E}+58$ & \\
Log likelihood & -4476.961 & \\
Akaike information criterion & 151.3987 & \\
Schwarz criterion & 153.6676 & \\
\hline \hline
\end{tabular}

The above Error Correction estimate shows that the out of equilibrium model can be adjusted back to equilibrium by $20.2 \%(-0.202982)$. This is upheld based on the anticipated negative assigned coefficient of the Error Correction estimate (CointEq1). Which is seen to be significant as the t-statistics of -2.31752 is greater than $-/+1.98$ or 2 . The above Error Correction estimate shows that the out of equilibrium model can be adjusted back to equilibrium by $20.2 \%(-0.202982)$. This is upheld based on the anticipated negative assigned coefficient of the Error Correction estimate (CointEq1). Which is seen to be significant as the t-statistics of -2.31752 is greater than $-/+1.98$ or 2 . The long run coefficient shows that subject to variations, both Audit Reporting Lag (ALG) and Disclosure quality (DQT) showed significant t-statistics of -16.8328 and 17.7481 respectively. This shows that in the long run, Relevance expenditure and Disclosure quality (DQT) represents fundamental factors that positively stimulates earnings per share of oil companies in Nigeria while Audit Reporting Lag (ALG) is seen to have reduced the ability of firms to maximize profit whereas Faithful Representation showed no significant influence on earnings per share (EPS).

\section{Test of Hypotheses}

$\mathbf{H}_{1}$ : There is no significant relationship between Audit Reporting Lag (ALG) and Earnings per share of oil companies in Nigeria.

The Error correction Model coefficient of -325.8053 shows a negative sign and its t-statistics of -16.8328 which is seen to be greater than the standard tabulated value of \pm 1.98 or 2 leads to the rejection of the null hypothesis. The study thus concludes that there is a significant relationship between Audit Reporting Lag (ALG) and Earnings per share of oil companies in Nigeria. Even though the empirical results are clearer, the empirical results however contradict the findings of some research scholars (Wet \& Mpinda, 2015; Mironinc 2016) who in their empirical study documented a positive and insignificant relationship between accounting information quality and financial performance of manufacturing companies in South Africa.

$\mathbf{H}_{2}$ : There is no significant relationship between Disclosure quality (DQT) and Earnings per share of oil companies in Nigeria. 
The Error correction Model coefficient of 497.0501 shows a positive sign and its t-statistics of 17.7481 which is seen to be greater than the standard tabulated value of \pm 1.98 or 2 leads to the rejection of the null hypothesis. The study thus concludes that there is a significant relationship between Disclosure quality (DQT) and Earnings per share of oil companies in Nigeria. The empirical study results is not consistent with the findings of scholars (Rahmani \& Akbari, 2013; Gill; Biger., Mand \& Mathur, 2013; Akram., Butt \& Ijaz, 2015; Hosseinian \& Ramzani, 2016. Hence, the empirical result expected disagrees with findings of most previous empirical studies carried out like (Omar \& Sabur, 2017; Debnath, 2017) who document negative and significant relationship between disclosure quality and earnings per share of quoted manufacturing companies in United State of America.

\section{Conclusion and Recommendations}

The focus of this empirical study is to investigate the relationship between accounting information quality and firm performance of quote oil and gas companies under the time series data framework; spanning from 2009-2018 our empirical outcome provides evidence that the explanatory power audit reporting lag, quality disclosure positively relate to firm performance we therefore conclude that audit reporting lag and quality disclosure significantly relate to earnings per share.

Based on the empirical findings and concluding remark, this study recommends that:

(i) increased scrutiny by regulators (FRCN, CBN, SEC etc) over accounting flexibilities would help to curtail accounting discretions both deliberate and systematic so that accounting information in financial statements will faithfully represent the phenomena they purport to represent and future corporate scandals on oil and gas crises can be avoided.

(ii) Policy makers should look into the audit report lag of quoted oil and gas companies in Nigeria and formulate policies to enforce compliance with the stipulated filing or reporting requirements. 
Journal DOI: www.doi.org/10.46654/ij.24889849

\section{References}

Ahmad, S., Siddiqui, K.A \&, Aboplsawh, H.M(2020). Family SME's survival: The role of owner. Family and Corporate Social responsibility. Journal of Small Business and Enterprise Development, 27(2),281-297

Akanbi, T.A \& Adewoye, J (2018). Effects of Accounting Information System Adoption on the financial performance of central Bank in Nigeria. Journal of Accounting \& Marketing, 1(6), 1-6

Akanbi, T.A, \& Adewoye, J. (2018). Effects of Accounting information system adoption on the financial performance of commercial bank in Nigeria. Journal of Accounting \& Marketing, 1(6), 1-6

Akesinro, S. \& Adetoso, J. (2016). The effects of computerized accounting system on the performance of banks in Nigeria. Journal of Economics and Sustainable Development, 7(14), 76-82

Al-Dalabih F.A (2018). The impact of the use of accounting information system on the quality of financial data. International Business Research, 11(5), 143-158

Ali, B., Bakar, R \& Omar, W(2016). The critical success factors of Accounting Information System (AIS) and its impact on organizational performance of Jordan commercial banks International Journal of Economics, Commerce and Management, 4(4),658-677

Alnajjar, M(2017). Impact of Accounting information system on organizational performance: A study of SME's in the UAE. Journal of Accounting \& Finance, 3(1),2035

Borhan, O \& Nofees, A (2018). Effects of accounting information system on financial performance: A study of selected real estate companies in Jordan. India Technical Research Organization, 5(1),41-50

Budairi .J.G (2017). The effect of quality of accounting information on financial statements on the decisions of its users, an applied study in a group of Iraqi companies. Al-Ghari Journal of Economic and Administrative Sciences 14(1),355-388

Dandago, K. Rafai, A (2014). Information technology and accounting system in the Nigerian banking industry. Asian Economic and Financial Review, 2(10),1-9

Dekeng, S. \& Prabowo, M (2015). Accounting information system alignment and Smes performance. A literature Review. International Journal of Management, Economics \& Social Sciences, 4(2),58-70

Denos, P., Holt, D.L. \& Imholf, E.A. (2019). The use of accounting information in bank lending decisions Accounting, Organizations and Society, 14(3), 235-246

Eb, A., Pretorious, P \& Zuva, T 92013). The role of accounting information system in accounting firm. International Journal of Accounting, Advanced Computer Research, $1(2), 21-31$

Esmeray, A (2016). The impact of accounting information systems in firm performance: Empirical evidence in Turkish small and medium sized enterprises. International Review of Management and Marketing, 6(2),233-236

Farah, N., Farrukh, I \& Faizan, N92016). Financial performance of firms: Evidence from Pakistan Cement industry Journal of Teaching and Education, 5(1),81-94

Hla, D \& Teru, S (2015). Efficiency of accounting information system and performance measures: Literature Review International Journal of Multidisciplinary and Current Research, 3(3),976-984

Ironkwe U.I. \& Nwaiwu, J.N(2018). Accounting information system on financial and Nonfinancial measures of companies in Nigeria. International Journal of Advanced Academic Research/Business Development \& Management, 4(2),39-55 
Journal DOI: www.doi.org/10.46654/ij.24889849

Isa, A (2017. The impact of computerized accounting information system on management performance in public sector in Nigeria: Problem and Prospects. International Journal of Multidisciplinary Research and Development, 4(1),80-83

Kashif, B (2018). Impact of Accounting Information system on the financial performance of selected FMCG companies. Asian Journal of Allied Sciences and Technology, 2(3),817

Khan,A (2017). Impact of Accounting information system on the organizational performance: A case study of Procter and Gamble. Star Research, 5(12),20-30

Mahdi, S., Mahmond, L., Mostafa, B. \& Ebadohollah, T (2015). The effect of implementation of accounting information system on efficiency, profitability and productivity of SMEs in Iran. Banks and Bank Systems, 10(3),79-86

Manchdot, T. (2019). A review of determinants Accounting information system adoption. Science Journal of Business Management, 7(1),17-22

Mitchell, T. Biykan, A. Oniken, G \& Fiedler, F (2017). The contingency model: Criticism and suggestion Academy of Management Journal, 13(3),1-23

Nizor, S., Ahmad, F \& Mohamad,M.(2016). Evaluate of accounting information systems in meeting the requirements of financial and managerial performance. Field study in the United Arab Emirates private Hospitals. International Journal of Humanities and Social Science, 6(4),170-196

Obaidat A/N (2017). Accounting information qualitative characteristics gap: Evidence from Jordan International Management Review, 3(2),26-32

Odar, M., Kravic, S \& Jermon M. (2015). The role of management Accounting system in decision-making process: Evidence from a post-transactions economy. Engineering Economics, 26(1),84-92

Palazuelos, E., Crespo, A.H \& Delcorte, Z.M (2017). Accounting information and trust as determinants of credit granting to SMEs: The role of external audit. Small Business Economics, 51(4),861-877

Patal, S (2015). Effects of accounting information system on organizational profitability. International Journal of Research and Analytical Reviews, 2(1),72-77

Raed, K (2017). The impact of computerized accounting information system on management performance in public sector in Nigeria: problem \& Prospects. International Journal of Multidisciplinary Research and Development, 4(12),80-83

Rehab, U (2018). The impact of Accounting information systems on organizational performance. The context of Saudi's SMEs. International Review of Management and Marketing, 8(2),69-73.

Saeidi, H (2014). The impact of accounting information system on financial performance. A case study of TCS India. Indian Journal of Fundamental and Applied Life Sciences, $4(4), 412-417$

Samer,M (2016). The impact of the effectiveness of accounting information systems on operational performance in public listed industrial companies in Jordan. Journal of Social Sciences, 5(3),265-276

Taiwo, J (2016). Effect of ICT on accounting information systems and organizational performance: The application of information and communication technology on accounting information system European Journal of Business and Social Sciences, $5(2), 1-15$

Tera, S., IdoNdeyati, J (2017). A review of the impact of accounting information system for effective internal control on firm performance. Indian Journal of Finance and Banking, $1(2), 52-59$ 
International Journal of Advanced Academic Research | ISSN: 2488-9849

Vol. 7, Issue 6 (June, 2021) | www.ijaar.org

Journal DOI: www.doi.org/10.46654/ij.24889849

Article DOI: www.doi.org/10.46654/ij.24889849.s76161

Yaser, H., Mina, S \& Nor, A (2014). The impact of the effectiveness of accounting information system in Nigerian banking industries. Asian Economic and Financial Review, 4(5), 655-670 